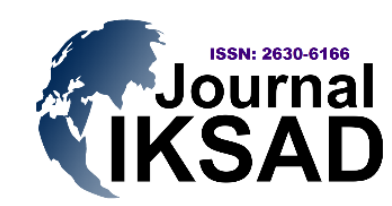

International Refereed \& Indexed

JOURNAL OF INSTITUTE OF ECONOMIC DEVELOPMENT AND SOCIAL RESEARCHES

ISSN: 2630-6166

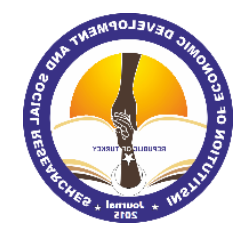

Sept. 2016 Open Access Refereed E-Journal

Vol:2 / Issue:4

Article Arrival Date 21/06/2016 The Published Rel. Date 14/09/2016 Published Date

p. 27-32

\title{
TURKIC INTEGRATION: PROBLEMS AND PROSPECTS
}

\section{ТЮРКСКАЯ ИНТЕГРАЦИЯ: ПРОБЛЕМЫ И ПЕРСПЕКТИВЫ}

\author{
Gulzhahan KHAJIEVA \\ Prof. Dr, Turan University khajieva@mail.ru
}

Определяющей современной тенденцией стала трансформация однополярной модели мира в многополярную. Формируются новые, непривычные с позиций вчерашнего дня форматы межгосударственного общения, имеющие необычные географические, цивилизационные и функциональные параметры. Время глобальных перемен открывают новые возможности для внедрения и распространения прорывных технологий, перехода к «экономике знаний», соединения потенциала развитых и развивающихся стран. Достичь этой цели невозможно без изменения методологии взаимодействия, без обращения к интеграции как к главному инструменту строительства нового, более справедливого миропорядка.

В связи с этим, международная интеграция становится одним из основных трендов развития современного мира. При этом различные формы интеграционного объединения стран могут быть устойчивыми в том случае, если они опираются как на экономические, так и на мощные цивилизационные факторы. Интернационализация экономики, энергично проводившаяся западными державами в начале XX-го столетия, создала предпосылки для появления нового ее качества - глобализации. Однако усиливающиеся экономические связи не смогли свести человечество воедино, они лишь привели к взаимодействию изолированные ранее друг от друга цивилизации. Мир стал более взаимосвязанным и взаимозависимым, но далеко не однородным. При этом формационные различия уступили цивилизационным особенностям.

Каковы же возможные варианты организации геополитического пространства, сущность и природа возникающих структур, как в целом влияют глобальные тенденции на региональные процессы? Какую роль в условиях трансформации глобального мира играет цивилизационный фактор? Создание интеграционного союза тюркских государств является одним из подобного рода геополитических сценариев.

В мире существует шесть стран, где главную роль играют именно тюркские этносы. Это Турция, Азербайджан, Узбекистан, Казахстан*, Кыргызстан и Туркменистан. Более того, в тюркский ареал попадают также регионы, автономии и национальные республики, входящие в состав государств, отличных по этническому признаку. В данном случае речь идет о Республике Башкортостан, Кабардино-Балкарской Республике, Карачаево-Черкесской Республике, Республике Татарстан, Республике Тыва, Республике Крым и других (Россия), Синьцзян-Уйгурском автономном районе (Китай), Гагаузии (Молдавия).

Развитие «тюркской интеграции» свидетельствует о том, что, помимо основных «фигурантов» (США, Китай, Россия), на центральноазиатской арене все более активно заявляют о себе другие политические «игроки». Здесь наряду с «тюркскими интеграционистами» активно работает Иран с его «персоязычным альянсом», здесь и 
Индия, громко заявившая о своем присутствии, заключив соглашение о стратегическом партнерстве с Афганистаном.

Поэтому в Турции, самом крупном тюркском государстве, восприняли образование на постсоветском пространстве новых независимых центральноазиатских республик как появление благоприятных условий для начала тюркской интеграции. Центральноазиатское направление сразу стало одним из приоритетных в турецкой внешней политике. Основой формирования максимально возможного бесконфликтного комплекса интересов является общетюркское историческое наследие, этнокультурная, конфессиональная, языковая общность тюркских государств. Именно цивилизационная близость интегрирующихся стран обеспечивает фундамент и устойчивость данного объединения.

Цивилизации, являясь высшей мерой идентичности в масштабах человечества, приобретают особую роль в периоды больших исторических переходов, к которым относится и современная эпоха. Обострение кризисных явлений практически во всех важнейших сферах общественной жизни требует обращения к фундаментальным характеристикам и механизмам развития, анализ которых поможет найти причины и способы преодоления возникших проблем. Функциональное значение универсальных, подчиняющихся общим законам социальных структур состоит в обеспечении более высокой степени стабильности, чем у разнородных. Однако оборотной стороной универсализации является разрушение национальной культурной самобытности, затрудняющее поиск ответов на новые, нетрадиционные вызовы. Эволюция как человеческой цивилизации, так и природы свидетельствует о том, что именно многообразие являлось магистральным направлением и гарантией поступательного движения.

Цивилизация, опираясь на социокультурные традиции и исторический опыт, помогает задействовать глубинные механизмы развития, сохранять целостность в условиях трансформации, не позволяя изменениям оказывать разлагающее влияние.

Смогут ли тюркские народы задействовать потенциал интеграции на основе цивилизационной общности? Ведь, несмотря на историческую культурную близость тюркских народов, в течение последних двух столетий они входили в состав различных, часто враждебных или изолированных друг от друга империй, внутри которых нередко проводилась политика «Разделяй и властвуй», что явилось причиной цивилизационного разобщения между тюркскими народами.

Необходимо также отметить, что в научной литературе понятие «тюркская цивилизация» появилось сравнительно недавно. Среди исследователей ведутся дискуссии о правомерности понимания тюркского мира как самостоятельной цивилизации.

Казахстанский философ С.Ш. Аязбекова, исходя из принятой теории цивилизации, рассмотрела цивилизационные параметры применительно к тюркскому миру. Анализ последнего с точки зрения таких признаков цивилизации, как единство территории и общность условий проживания, государственность, языковое родство, наличие религии и письменности, развитая система экономических отношений, единство или близость экономического и политического строя, культуры и менталитета, позволил ей заключить, что тюркский мир создал свою неповторимую цивилизацию, коренным образом отличающуюся от других цивилизаций [1].

В силу своего долгосрочного и фундаментального характера цивилизационное единство может рассматриваться в качестве объекта интегрирования тюркского сообщества. Так, Ю.Г. Барсегов обращает внимание на то, что доктрина тюркизма рассчитана на длительные сроки и должна реализовываться постепенно, двигаясь к 
более тесным формам общетюркского политического объединения, хотя, по мнению автора, учитывая национализм тюркских народов СНГ, турки не ставят задачу объединения их в одно государство, рассчитывая скорее на создание союза тюркоязычных государств [2].

Чарлз У. Хостлер определяет «тюркизм» как «движение, стремящееся к политическому и культурному единству всех тюркоязычных народов» [3, p.63]. Схожее с ним определение «тюркизма» дает Якоб Ландау, рассматривая его как «движение, целью которого является создание объединения, союза - на культурной, психологической (или на обеих вместе) основах - народов тюркского происхождения» [4, p.51].

В этих характеристиках подчеркивается первостепенная важность именно фактора культурной, психологической и коммуникативной близости тюркских народов. Исходя из чего, к основной цели тюркизма в XXI веке можно отнести создание единого культурного и информационного пространства, охватывающего весь тюркский мир, т.е. углубление цивилизационной общности тюркских народов.

Насущность решения задачи тюркского сотрудничества имеет под собой ряд факторов, необходимых для обеспечения жизнеспособности интеграционного союза и предопределяющих общность интересов. К факторам и предпосылкам тюркской интеграции можно отнести, прежде всего, следующие:

$\checkmark$ необходимость совместных усилий по сохранению и развитию культурного и духовного потенциала тюркского мира;

$\checkmark$ необходимость консолидации потенциалов тюркских регионов в условиях регионализации всего мира;

$\checkmark$ необходимость централизованного отстаивания интересов субъектов тюркского мира, находящегося в центре Евразии на пересечении интересов наиболее мощных глобальных игроков;

$\checkmark$ общность геоэкономических интересов, обусловленная, в частности, внутриконтинентальным расположением большинства тюркских стран и сопряженной с этим оторванностью от моря, замкнутостью друг на друге и необходимостью совместного выхода к морю и дополнительных транспортных маршрутов.

Начало интеграционным процессам положило создание в 1991 году Всемирной Ассамблеи тюркских народов - организации, занимающейся «воссозданием, разработкой и пропагандой тюркского пути общественного развития». В 1992 году в Анкаре впервые состоялся саммит глав тюркоязычных стран, завершившийся рядом договоренностей пока только в гуманитарно-культурном сотрудничестве. В следующем году, по итогам визита Тургута Озала в Центральную Азию и Азербайджан, президентами тюркоязычных стран был подписан Протокол о создании содружества тюркоязычных стран. 12 июля 1993 года, по соглашению, подписанному в Алма-Ате, была создана Организация по совместному развитию тюркской культуры и искусства ТЮРКСОЙ. Однако первое десятилетие интеграционных усилий не дало практических результатов.

Идея необходимости сближения и развития сотрудничества между тюркскими народами вновь зазвучала на 8-м саммите глав государств четырех тюркоязычных стран (Азербайджан, Казахстан, Кыргызстан, Турция), состоявшемся 17 ноября 2006 года в Анталье. Главным событием встречи стала инициатива казахстанского президента Назарбаева о создании Межпарламентской ассамблеи тюркоязычных государств, что, по мнению экспертов, подтверждало заинтересованность казахского лидера в полномасштабном сотрудничестве тюркских стран. На саммите в Анталье 
также были достигнуты договоренности по укреплению связей в области энергетики и безопасности. В этой связи была подписана итоговая декларация о необходимости интенсификации экономических и транспортных связей между тюркскими странами, что свидетельствовало о расширении круга взаимных интересов тюркских государств.

3 октября 2009 года на 9-м саммите в Нахичевани по инициативе главы независимого Казахстана принято соглашение «О создании Совета сотрудничества тюркоязычных государств». Тюркский совет должен был обладать «всеми необходимыми признаками политического регионального объединения, правовым статусом и определенными организационными структурами». Помимо самого совета, Казахстан предложил создать ряд общетюркских институтов: Центр изучения тюркского мира и Тюркскую академию, а в ее составе - Центр тюркской истории и культуры, Центр изучения тюркского языка, Тюркскую библиотеку и Тюркский музей. Практически все предложения Назарбаева были приняты.

В Нахичевани еще больший акцент был сделан на энергетической стороне «тюркской интеграции», в первую очередь, в области обеспечения многовариантности транспортировки энергоресурсов (то есть возможность прокладки трубопроводов и прочих транспортных артерий в обход России). В принятой в Нахичевани декларации особо подчеркивалось стратегическое значение нефте-и газопроводов Баку-ТбилисиДжейхан и Баку-Тбилиси-Эрзурум в обеспечении глобальной энергетической безопасности и устойчивому экономическому развитию стран региона. В этой связи главы государств отметили важность увеличения пропускной способности трубопровода Баку-Тбилиси-Джейхан и придали особое значение связи между портом Актау и нефтепроводом Баку-Тбилиси-Джейхан». В целом же, конечно, нужно согласиться, что именно энергетические ресурсы, которыми так богата Центральная Азия, имеют наибольшие шансы стать ключевым звеном «тюркской интеграции».

По итогам юбилейного 10-го саммита, который состоялся в сентябре 2010 года в Стамбуле, был официально учрежден Совет сотрудничества тюркоязычных государств, а также созданы институты, необходимые для практической реализации идеи тюркской интеграции.

Примечательно, что с октября 2011 г. саммиты стали проходить уже в новом формате, как саммиты Совета сотрудничества тюркоязычных государств (ССТГ). Первый саммит ССТГ принимал Алматы. Новая модель взаимодействия опирается на три главных компонента: совместное решение вопроса в сфере безопасности, оптимизация торгово-экономического сотрудничества, включая энергетическую сферу, и, наконец, культурно-языковые аспекты интеграции тюркских государств, на реализацию которых как раз направлена деятельность ТЮРКСОЙ.

Второй саммит ССТГ состоялся 23 августа 2012 года в Бишкеке, на котором большое внимание было уделено экономическому сотрудничеству стран Совета, прежде всего транспортным коммуникациям между странами. Участники Саммита подписали протокол о создании железнодорожного коридора с маршрутом: Турция (Карс) Тбилиси - Баку - Каспий - Казахстан - Кыргызстан - Китай, соглашение по финансовым правилам Совета сотрудничества тюркоязычных государств и другие документы.

На третьем саммите ССТГ, проходившем 16 августа 2013 года в г. Габала Азербайджанской Республики основной темой обсуждения стали вопросы сотрудничества в сфере транспорта и упрощения таможенных процедур. Участники саммита отмечали, что реализация транзитного потенциала стран участниц ССТГ и совершенствование транспортной инфраструктуры открывает большое будущее. В частности, по мнению экс-президента Турции Абдулла Гюль «современная концепция Шелкового пути является энергетическим, транспортным и логистическим проектом, 
который внесет вклад в развитие всего региона. Эти проекты превратят тюркский мир в центр развития мировой экономики».

Президент Казахстана Нурсултан Назарбаев, выступая на саммите, отметил недостаточный уровень и неэффективность нынешних торговых отношений между странами: "В настоящее время торговый оборот между шестью независимыми тюркоязычными странами составляет 1 трлн. 150 млрд. долларов. Эта цифра не отражает потенциал наших стран. Мы должны укрепить наши экономические связи и увеличить торговый оборот". Он озвучил ряд инициатив по дальнейшей интенсификации интеграционных процессов стран тюркского мира: «Транспорт и коммуникации должны стать основой для развития нашей экономической мощи...Мы планируем в 2020 году увеличить транзитные перевозки через Казахстан в два раза, а к 2050 году - в 10 раз. В будущем планируется довести грузоперевозки по территории страны до 50 миллионов тонн в год» [5, с.4].

Таким образом, исторические связи, общность целей и задач, сходство проблем тюркоязычных стран, являются одним из важных факторов, объединивших тюркские народы. Условием региональной интеграции является стремление к интегрированию всех тюркских народов в едином пространстве, а главное - обеспечение достойного представления интересов тюркских народов в данном объединении, в том числе и путем консолидированного отстаивания интересов тюркских народов.

Однако процесс интеграции тюркских стран сталкивается сегодня с целым рядом проблем, среди которых необходимо выделить следующие.

Во-первых, в состав ССТГ сотрудничества не вошли Туркменистан и Узбекистан, а это означает, что в Тюркском совете не участвует большая часть тюркского населения Центральной Азии. К тому же Туркменистан обладает крупнейшими в регионе и вторыми в мире после России запасами природного газа, экспорт которого мог бы стать локомотивом экономической интеграции.

Во-вторых, базовой проблемой тюркского мира является и отсутствие общих границ. Если Казахстан, Киргизия, Туркмения и Узбекистан граничат друг с другом, то от Азербайджана их отделяет Каспийское море. Общей границы с Турцией фактически не имеет и Азербайджан. На небольшом участке с ней граничит входящая в состав Азербайджана Нахичеванская автономная республика, которая, однако, отделена от основной территории страны Арменией. Территориальная удаленность основных центров тюркского мира препятствует реализации совместных экономических проектов.

В-третьих, все участники Тюркского совета обладают разным экономическим весом. По размеру ВВП Турция примерно в три раза опережает Азербайджан, Казахстан и Киргизию вместе взятые. Турция, благодаря своему экономическому потенциалу, вне всяких сомнений будет играть ключевую роль в тюркском мире. Поэтому на пути реализации принципа равноправной интеграции стоят серьезные препятствия в виде большой разности экономических потенциалов.

В-четвертых, экономическое неравенство имеет и политические последствия. Степень привлекательности тюркской интеграции напрямую зависит от практического воплощения принципа равноправия, т.е. недопустимости гегемонии какой-либо страны, несмотря на естественную разницу во влиянии на этот процесс различных потенциалов отдельных тюркских народов и стран.

В-пятых, стержнем тюркской интеграции традиционно выступает гуманитарная составляющая, где центральным является вопрос общего языка. Как правило, необходимость его введения обосновывается ссылками на существовавшую некогда 
единую культурно-историческую общность. Однако существуют определенные проблемы с переходом на латиницу.

В-шестых, несмотря на то, что идея создания зоны свободной торговли обсуждалась неоднократно и на различных уровнях, по мнению многих экспертов, в обозримом будущем «тюркская интеграция» едва ли может стать аналогом и тем более альтернативой тому же Таможенному союзу России, Белоруссии и Казахстана. Большинство экспертов оценивают вероятность создания подобного объединения как сомнительную. На сегодняшний день, ни одно тюркское государство не способно взять на себя роль ведущего центра и локомотива экономической интеграции. Поэтому в качестве одной из главных целей создания тюркской парламентской ассамблеи тюркоязычных государств определено создание условий для экономической и политической интеграции тюркоязычных государств.

Таким образом, с одной стороны, интеграционные инициативы, воплотившиеся в Тюркском совете, свидетельствуют о формировании новой цивилизационной парадигмы тюркского мира, открывающей новые возможности и пространства для сотрудничества, а с другой стороны - о наличии довольно больших противоречий между тюркскими государствами.

\section{Примечание:}

* Многонациональный состав народа Казахстана всегда являлся и является одним из преимуществ нашего государства. Представители 20 тюркоязычных этни ческих групп проживают в мире и согласии со всеми этносами Казахстана. Безусловно, тюркские этнические группы Казахстана играют важную роль в социально-экономическом развитии страны. Согласно последним статистическим данным, казахи составляет большинство населения $(66,01 \%)$ и, соответственно, являются самым крупным тюркским этносом Казахстана. Следующими крупными тюркскими этносами, населяющими страну, являются узбеки $(3,07 \%)$ и уйгуры $(1,44 \%)$.

1. Аязбекова С. Ш. «Тюркская цивилизация» в системе цивилизационных классификаторов // Альманах "VIA EVRASIA" 2012, №1. Источник: http:/www.viaevrasia.com/ru

2. Барсегов Ю.Г. Геополитическая угроза России. - М., 1996.

3. Hostler Ch.W. Türken und SowjetS. Die historische Lage und die politische Bedeutung der Türkvölker in der heutigen Welt / Ch.W. Hostler - Frankfurt/Main; Berlin, 1960.

4. Landau J. Pan-Turkism in Turkey. A Study of Irredentism / J. Landau - London, 1981.

5. Осипов В. Расширяя горизонты сотрудничества // Казахстанская правда - 31 декабря 2013 года, № 347 (27621) 